\title{
Comparative Study Between Low Level Laser and Therapeutic Ultrasound in Second Intention Ulcers Repair in Mice
}

\author{
Aline Carla Teles de Sousa ${ }^{1}$, Ítalo Bruno Paiva da Rocha ${ }^{1}$, Ana Flávia Machado de Carvalho ${ }^{2 *}$, Nayana Pinheiro \\ Machado de Freitas Coelho ${ }^{3}$, Maura Cristina Porto Feitosa ${ }^{4}$, Esmeralda Maria Lustosa Barros ${ }^{5}$, \\ Emilia Angela Lo Schiavo Arisawa ${ }^{6}$, Maria Rosilândia Lopes de Amorim ${ }^{7}$
}

\author{
${ }^{1}$ Graduates of Physical Therapy, Integral Diferencial College (DeVry/FACID), R. Veterinário Bugija Brito, 1354 - Horto \\ Florestal Teresina - PI, Brazil \\ ${ }^{2} \mathrm{PhD}$ in Biometrics Engineering, Vale do Paraíba University (UNIVAP). Prof. PhD. depute of Integral Diferencial College \\ (DeVry/FACID). R. Deputado Afonso Gil, 5498, Santa Lia, Teresina - PI, Brazil \\ ${ }^{3} \mathrm{PhD}$ in Biometrics Engineering, Vale do Paraíba University (UNIVAP). Rua Miosótis, 303, ap. 2202, CEP 64049-536, Teresina \\ - Pl, Brazil \\ ${ }^{4} \mathrm{MSc}$ in Science Health, Federal of Piauí University (UFPI), Teresina, Brazil \\ ${ }^{5}$ Specialist in Applied Microbiology Science Health, Federal of Piauí University (UFPI). Av. Joaquim Ribeiro, 1291 - Centro. \\ CEP: 64.001-480 Teresina - PI, Brazil \\ ${ }^{6} \mathrm{PHd}$ in Oral Biopathology and Diagnosis, Odontology of São José dos Campos College (UNESP) \\ ${ }^{7}$ MEd in Letras, Federal of Piauí University (UFPI), Teresina, Brazil
}

\author{
*Correspondence to \\ Ana Flávia Machado de Carvalho \\ $\mathrm{PhD}$ in Biometrics Engineering; \\ Vale do Paraíba University \\ (UNIVAP). Prof. PhD. depute \\ of Integral Diferencial College \\ (DeVry/FACID). R. Deputado \\ Afonso Gil, 5498, Santa Lia, \\ Teresina - PI, Brazil. \\ Tel: +5586999861242 \\ Fax: +55 86999861242 \\ Email: \\ anaflaviaparaibana@hotmail.com
}

Published online 20 March 2017

\begin{abstract}
Introduction: An ulcer is an injury that affects the skin and has many causes. Healing is a way of protecting the body against any infectious agent that tries to infect you through the wound. Low level laser (LLL) in the treatment of ulcers, aims at maintaining the stability of the physiological process of tissue repair and ultrasound (US) acts by increasing the elasticity of tissue and scarring. The aim of this study was to analyze the effects of LLL and US in wound healing of ulcers induced in mice.

Methods: In this experimental study, a sample of 36 guinea pigs was divided into 6 groups of 6 mice, 2 groups as control (C7) and (C14), 2 treated with laser (GL7) and (GL14) and the others 2 treated with ultrasound (GU7) and (GU14). The ulcer was induced and after 7 days, 6 mice from each group were sacrificed to obtain the histological sections for analysis, and the remaining 6 mice from each group continued under treatment and in day 14 , they were sacrificed to obtain histologic specimens while macroscopic image was also carried out.

Results: Three aspects were analyzed, the percentage of wound regression where it was observed that there was a significant difference in the first 7 days. Regarding the inflammatory process, it was observed that in the first 7 days GL7 and GU7 improved significantly and within 14 days of the experimental period GU14 showed a significant difference when compared to C14. The number of fibroblasts present in the GL at 7 days showed a significant difference compared to the others, and at 14 days, the US group had a significant difference compared to the other groups. Conclusion: Thus, it was evident that the US had more effective results with anti-inflammatory action, better organization and increased deposition of collagen and fibroblasts. Therefore, it can be concluded that other studies are consistent with this taking into account the laser must be used during the early days of the initial healing process and the US during the end of this process. Keywords: Ulcer; Healing; Laser; Ultrasound.
\end{abstract}

\section{Introduction}

The skin is the body's protective barrier against external agents and therefore it is subject to constant attacks. Ulcers are discontinuities in the skin that cause anatomical changes and have severity levels, which make them, sometimes, difficult to treat. ${ }^{1}$

Wound healing is the process in which the injured tissue is replaced by new revascularized tissue. Thus, the healing process has the reestablishment of homeostasis and protection against external agents, as some of the main objectives. Therefore, it is necessary to understand this process, so that through therapeutic resources this healing process is accelerated. ${ }^{2}$

Ultrasound (US) is a widely used resource in the treatment

Please cite this article as follows: de Sousa ACT, da Rocha ÍBP, de Carvalho AFM, et al. Comparative study between low level laser and therapeutic ultrasound in second intention ulcers repair in mice. J Lasers Med Sci. 2018;9(2):134-138. doi:10.15171/jlms.2018.25. 
of skin ulcers. It uses sound energy to produce mechanical vibrations in the body's cells. These vibrations produce heat in the tissue, which bring several positive stimulus to cells. In order to have an efficient healing, the parameters of the apparatus must be properly applied according to the stage of lesion. ${ }^{3,4}$

Laser uses non-ionizing radiation and has some characteristics, such as monochromaticity. They are classified into high intensity and low-level lasers. Laser irradiation stimulates physiologic processes, e.g., favoring the production of arachidonic acid and an increase in intracellular ATP production, which will also accelerate healing, enhancing the inflammatory process and decreasing the edema. ${ }^{5,6}$

As there are several alternative treatment protocols related to tissue repair in humans, we developed this study expecting to find out which therapeutic resource, low-level laser or US is more effective in the tissue healing process in humans. This knowledge may enable a direction for the treatment in humans, reducing the time of intervention, morbidity and consequent improvement in quality of life.

\section{Methods}

\section{Animals}

Thirty-six mice were used, weighing between 200 and $300 \mathrm{~g}$, kept in a vivarium at Integral Diferencial College, Teresina - PI, in individual cages with food and water ad libitum and dark light cycle (12 hours).

\section{Experimental Groups}

The animals were separated randomly into 6 equal groups, with 6 mice each, treated as follows:

Group 1: Control 1 (C7)

Group 2: Laser group 1 (GL7)

Group 3: Ultrasound group 1 (GU7)

Group 4: Control 2 (C14)

Group 5: Laser group 2 (GL14)

Group 6: Ultrasound group 2 (GU14)

\section{Surgical Procedures}

To perform the experiment, the animals were weighed, and properly anesthetized with intramuscular ketamine $(100 \mathrm{mg} / \mathrm{mL})$ and xylazine $(20 \mathrm{mg} / \mathrm{mL})$ at a dose of 50 $\mu \mathrm{l} / 100 \mathrm{~g}$ volume of body mass. Once anesthetized, the mice were placed in prone position to perform the trichotomy of the dorsal region and carry out local asepsis with povidone iodine topical solution. A leaked pattern was used to delimit under the exposed area an $0.8 \mathrm{~mm}$ diameter circular surface. Then the skin exteresis was performed by incision, duly respecting the markings. Immediately after the incision, pentabiotic (L.A. Penikel) was administered in order to maintain analgesia to prevent pain in the animals. A volume $50 \mathrm{~L} / 100 \mathrm{~g}$ body mass was also injected during the treatment.

\section{Experimental Procedure}

Two groups of low level laser (LLL) (GL7 and GL14), gallium arsenide (GaAs) with wavelength $904 \mathrm{~nm}$, radiant exposure $3-6 \mathrm{~J} / \mathrm{cm}^{2}$ and average power $0,01 \mathrm{~W}$. Two groups of pulsed ultrasound (GU7and GU14) at 20\% intensity between 0.8 and $1 \mathrm{~W} / \mathrm{cm}$ and frequency of $3 \mathrm{MHz}$ for 5 minutes. And two more groups used as control without any treatment, C7 and C14 groups.

The study was carried out for 14 days in total. The ulcer was induced and after 7 days, the C7, GL7 and GU7 mice groups were sacrificed to get the material aiming at the histological slides for analysis. The other GL14 and GU14 groups, except C14 remained for seven other days in treatment, then were also subjected to euthanasia after 14 days in order to obtain histological slides for comparative analysis.

Morphometric Analysis and Euthanasia

The determination of the lesion area and its macroscopic aspects was performed via measurement and digital photographic record of the wounds of all the animals, maintaining a standard $30 \mathrm{~cm}$ of height of the lesion in the postoperative period, that is, days zero, 7 th and 14 th of treatment. The images were sent to the software Image $J$ and precise calculations of the measures in the areas of injury and their regressions were made.

The animals were sacrificed on the 7 th and 14th days to obtain tissue for analysis of histological slides. Euthanasia was performed by intraperitoneal (IP) overdose of sodium pentobarbital anesthetic. After sacrifice, which lasted about 15 minutes, the animals were carefully observed to confirm full respiratory arrest and death. After that, the histological slides were collected and finally the animals discarded, which had been carried out by the laboratory technician responsible for the vivarium.

\section{Histological Analysis}

Each wound was dissected with a margin of $1 \mathrm{~cm}$ around the lesion in a depth that reaches the back of the animal muscle then placed in a bottle with $10 \%$ formalin. Then, each piece went through a routine process for inclusion in paraffin. After getting into blocks, longitudinal sections were made with a 0.5 -micrometer thickness on a rotary microtome, these cuts were subjected to hematoxylineosin (HE).

The analysis was based on fibroblast proliferation criteria, deposition of collagen fibers, vascular proliferation, cell infiltrate nuclear polymorph or mononuclear and reepithelialization using a binocular optical microscope with photo on $40 \mathrm{x}$ for cell differentiation.

\section{Data Analysis}

The data were evaluated by GraphPad Prism program, version 9.0, with one-way analysis of variance (ANOVA) analysis and post hoc Tuckey, considering 5\% significance 
level $(P<0.05)$. To verify the normality, the data were submitted to the normality test of D'Agostino \& Pearson with 95\% confidence level.

\section{Results}

For wound regression percentage, it was observed that at 7 days, comparing GL7 and GU7 groups with the control (C7), there was a significant difference $(\mathrm{p}<0,01)$. But after 14 days of wound contraction, no significant difference was observed between the intervention groups (Figure 1). In the statistical analysis of the inflammatory process, it was observed that at 7 days, the GL7 and GU7 groups improved significantly $(P<0.001$ and $P<0.01$ respectively $)$ compared to C7. On the 14-day, the GU14 group showed a significant difference $(P<0.01)$ when compared to the C14 group (Figure 2).

When we compare the numbers of fibroblasts present in the GL group at 7 days, a statistically significant difference with $P<0.01$ was shown, compared to the other groups. At 14 days, it was observed that comparing the GL14 and GU14 groups with the C14 group, there was also a statistically significant difference with $P<0.001$, with Ultrasound being more significant (Figure 3 ).

\section{Discussion}

The healing process of pressure ulcers according to Cristina ${ }^{7}$ improved in patients treated with LLL therapy, GaAs of $904 \mathrm{~nm}$ at a dose of $6 \mathrm{~J} / \mathrm{cm}^{2}$ for 14 sessions. This observation is opposite to the findings of Moreira and Campmany ${ }^{8}$ study on laser performance in ulcer healing, where GaAs laser got better results, promoting better organization of collagen and increased vascularization of scar tissue.

Vieira and Ortiz ${ }^{9}$ demonstrated in a case report that the use of laser AlGaInP $660 \mathrm{~nm}$, intensity $4 \mathrm{~J} / \mathrm{cm}^{2}$, applied twice a week, showed significant improvement after the tenth session in a grade 3 pressure ulcer.

In the research conducted by Ramires and Meija, ${ }^{10}$ it was

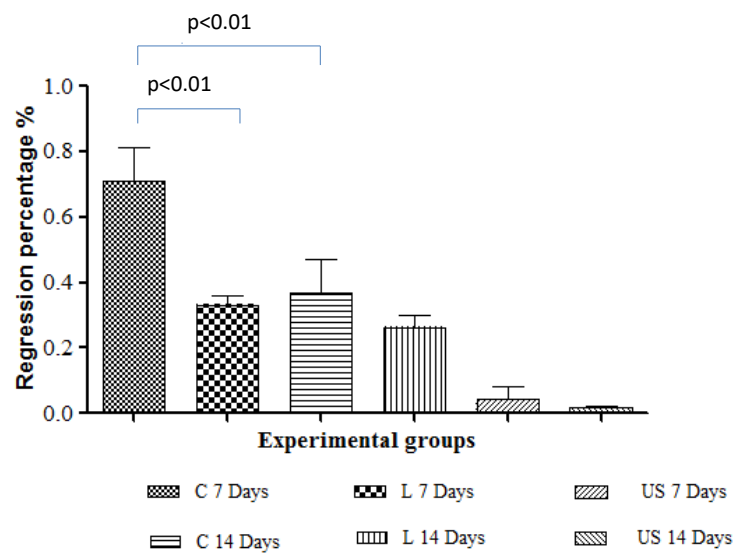

Figure 1. Percentage of Regression of the Area Assessed at 7 and 14 Days for the Groups. shown that the treatment of pressure ulcers through low intensity laser therapy demonstrated such significant improvements that patients did not need to undergo surgery, as this method has the property of recovering injured tissue. As Freire et $\mathrm{al}^{11}$ had shown in a study in which laser was applied to excised ulcers, laser was effective in various skin lesions, even if it was applied with different intensities and apparatus.

Ayuk et $\mathrm{al}^{12}$ in their study revealed that the use of $\mathrm{HeNe}$ laser on wound healing, stimulates the production of collagen and fibroblasts, as well as the increase of their migration to the scar area. Sanati et $\mathrm{al}^{13}$ in their study, compared the use of GaAs and HeNe laser in 30 rats for 21 sessions which resulted in a faster closure of the lesion in the group treated with GaAs. The group using $\mathrm{HeNe}$ obtained relevant results in comparison with the control group.

According to Leite ${ }^{14}$ study, using GaAs laser $780 \mathrm{~nm}, 3-8$

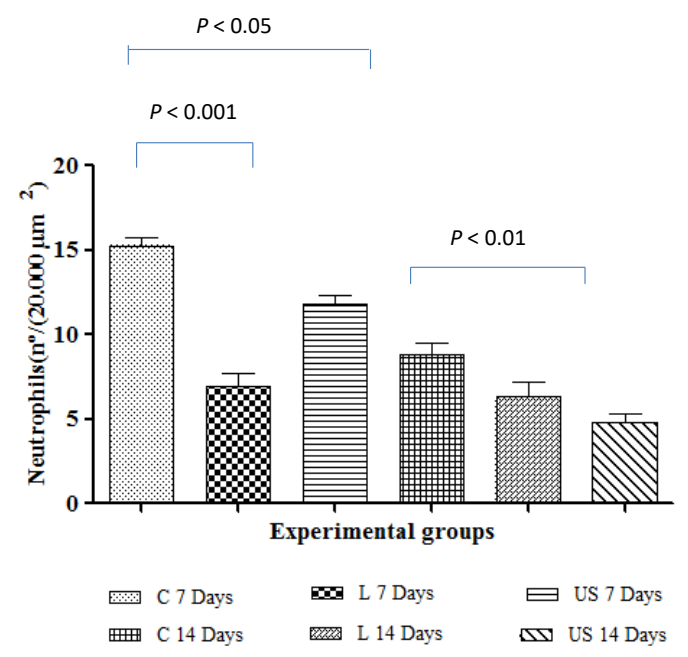

Figure 2. Number of Neutrophil $\left(20.000 \mu \mathrm{m}^{2}\right)$ on Days 7 and 14 Treated With Laser and Ultrasound.

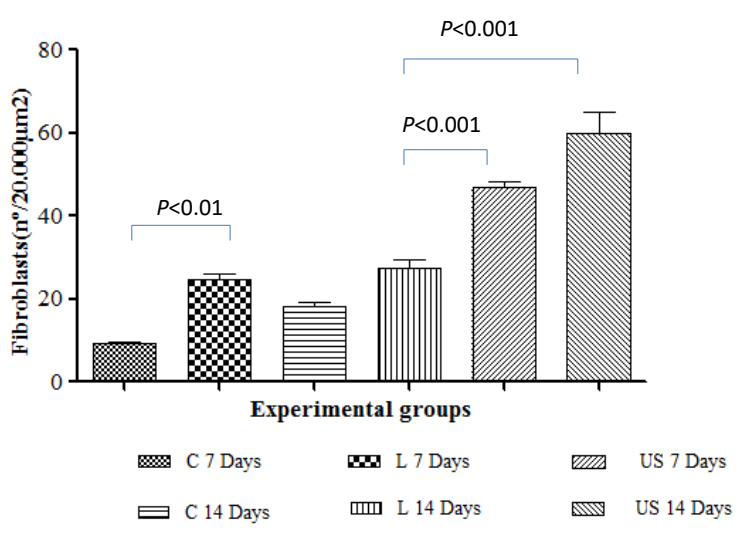

Figure 3. Number of fibroblast $(20.000 \mu \mathrm{m} 2)$ on Days 7 and 14 Treated With Laser and Ultrasound. 
$\mathrm{J} / \mathrm{cm}^{2}$ intensity, $15 \mathrm{~mW}$ power for 7 days in cutaneous ulcers induced in rats, it can be observed an increased fibroblast proliferation in the scar tissue.

In addition to these properties restored through treatment with GaAs laser, there was an improvement in collagen organization and increased tissue vascularization according to Cristina ${ }^{7}$ and Moreira and Campmany, ${ }^{8}$ respectively. These histological results were corroborated in this study.

However, Martins et a ${ }^{15}$ reported that US has been widely used in physiotherapy for tissue repair in recent decades, and some work carried out were contradictory for both results and dosimetry.

Farcic et $\mathrm{al}^{16}$ in their research on the application of US in musculoskeletal tissue repair, reported that the wound begins to show reddish color indicating increased blood flow in the lesion, similar to our findings. Concluding that the most used time and essential to achieve good results is 5 minutes.

In this work, LLL had a great outcome in the first seven days regarding the increase in number of fibroblasts in the lesion, but the US had a more relevant increase on day 14 , as Oliveira et $\mathrm{al}^{17}$ showed in their research using low-intensity US.

Thus, it was evident that US showed better and more effective results with anti-inflammatory action, organization and collagen deposition, and fibroblasts population in the injured area, as Maiti ${ }^{18}$ and Carrer et $\mathrm{al}^{19}$ described in their researches. Therefore, with this understanding, although laser was effective tissue repair in several studies and during the first 7 days in this research, US becomes decisive in the treatment because during the last 7 days it had better healing action, compared to the laser. It can be said that other studies are consistent with these findings, and it should be taken into account that laser must be used during the early days of the initial healing process and the US during the end of this process.

\section{Conflict of Interests}

The authors declare that they have no conflict of interest.

\section{Ethical Considerations}

For the implementation of this study, we applied all the ethical principles of animal testing in accordance with the Federal Law No. 11,794/2008. The research project was approved by Ethics Committee on Animal Use (CEUA) of the Integral Diferencial College - DeVry/FACID under the protocol $n^{\circ} 06 / 15$.

\section{References}

1. Peplow PV, Chung TY, Ryan B, Baxter GD. Laser photobiomodulation of gene expression and release of growth factors and cytokines from cells in culture: a review of human and animal studies. Photomed Laser Surg. 2011;29(5):285-304. doi: 10.1089/pho.2010.2846.
2. Oliveira IVPM, DIAS RVC. Cicatrização de feridas: fases e fatores de influência. Acta Veterinaria Brasilica. 2012;6(4):267-271.

3. Amâncio ACG, Barbieri $\mathrm{CH}$, Mazzer N, Garcia SB, Thomazini JA. Estimulação ultra-sônica da integração de enxertos de pele total: estudo experimental em coelhos (Ultrasonic stimulation of total skin grafts union. an experimental study in rabbits). Acta Ortop Bras. 2006;14(5):276-279. doi:10.1590/S141378522006000500010.

4. Beduschi CD, Weiss C, Wolf LS. Transdução da energia sonora para sinais elétricos utilizando material piezoelétrico. http://repositorio.roca.utfpr.edu.br/jspui/ handle/1/3206. Published 2015.

5. Silva EM, Gomes SP, Ulbrich LM, Giovanini AF. Avaliação histológica da laserterapia de baixa intensidade na cicatrização de tecidos epitelial, conjuntivo e ósseo: estudo experimental em ratos (Histological evaluation of the effects of LLLT on the epithelial, connective and osseous tissue healing: experimental study in rats). Revista SulBrasileira de Odontologia. 2007;4(2):30-35.

6. Lins RDAU, Dantas EM, Lucena KCR, Catão MHCV, Granville-Garcia AF, Carvalho Neto LG. Efeitos bioestimulantes do laser de baixa potência no processo de reparo (Biostimulation effects of low-power laser in the repair process). Anais Brasileiros de Dermatologia. 2010;85:849-855.

7. Cristina E. Laser de baixa potência: um forte aliado ao tratamento cicatricial da úlcera de pressão em pacientes hospitalizados. Rev Min Ciência da Saúde. 2011;(3):35-42.

8. Moreira DO, Campmany WG. Cura e reparo induzida por laserterapia: revisão bibliográfica. 25p. Trabalho de conclusão de curso. Universidade São Francisco Bragança Paulista; 2015.

9. Vieira MB, Ortiz DA. Alicação do laser AlGaInP de 660 nm em úlcera de pressão grau 3: Relato de caso. 2010.

10. Ramires RC, Meija DPM. Os efeitos do laser no tratamento de úlcera de decúbito-Revisão Bibliográfica. Fac Ávila-Ter Man. 2012.

11. FREIRE, M. C. G. S. et al. Estudo histológico comparativo entre laser de baixa potência, própolis e associação de ambas sobre lesões de pele de Rattusnorvegicus albinos [dissertation]. Alfenas: Universidade José do Rosário Vellano; 2010.

12. Ayuk SM, Houreld NN, Abrahamse H. Collagen production in diabetic wounded fibroblasts in response to low-intensity laser irradiation at $660 \mathrm{~nm}$. Diabetes Technol Ther. 2012;14(12):1110-1117. doi: 10.1089/dia.2012.0125.

13. Sanati $\mathrm{MH}$, Torkaman G, Hedayati M, Dizaji MM. Effect of $\mathrm{Ga}-\mathrm{As}(904 \mathrm{~nm})$ and $\mathrm{He}-\mathrm{Ne}(632.8 \mathrm{~nm})$ laser on injury potential of skin full-thickness wound. $J$ Photochem Photobiol B. 2011;103(2):180-5. doi: 10.1016/j. jphotobiol.2011.03.003.

14. Leite SN. Fototerapia como estímulo à cicatrização de úlceras cutâneas em ratos frente ao estresse oxidativo experimental. Rev Bras Ciências Farm. 2014.

15. Martins BS, Portolez JL, Bertolini G. Estudo comparativo entre o efeito do Ultra-som terapêutico e do laser de Baixa potência em lesões tendinosas Induzidas em ratos. Revista UNILUS Ensino e Pesquisa. 2014;11(22):77-83. 
16. FARCIC TS, de Lima RMSB, Machado AFP, et al. Aplicação do ultrassom terapêutico no reparo tecidual do sistema musculoesquelético (Application of therapeutic ultrasound on tissue repair of the musculoskeletal system). Arquivos Brasileiros de Ciências da Saúde. 2012;37(3):149-153.

17. Oliveira PDd, Oliveira DAAP, Martinago CC, Frederico RCP, Soares CP, Oliveira RFd. Efeito da terapia ultrassônica de baixa intensidade em cultura celular de fibroblastos. Fisioterapia e Pesquisa. 2015;22:112-118.

18. Maiti SK, Kumar N, Singh GR, Hoque M, Singh R. Ultrasound therapy in tendinous injury healing in goats. J Vet Med A Physiol Pathol Clin Med. 2006;53(5):249-258. doi:10.1111/j.1439-0442.2006.00816.x.

19. Carrer VdM, Setti JAP, Veronez DdL, Moser AD. Continuous therapeutic ultrasound in the healing process in rat skin. Fisioterapia em Movimento. 2015;28:751-758. 